Tubagus Ali Rachman Puja Kesuma|

\title{
POLA INTEGRASI DALAM MASYARAKAT MAJEMUK (Studi Ketahanan Sosial di Kecamatan Kotagajah, Lampung)
}

\section{Tubagus Ali Rachman Puja Kesuma}

IAIN Metro, Lampung

email: king_rachman@yahoo.com, Hp. 085669683490

\begin{abstract}
Abstrak
Keanekaragaman suku dan agama di kecamatan Kotagajah memaksa masyarakatnya untuk hidup bersama dengan membawa perbedaan syariat, kearifan lokal dan kebudayaannya masingmasing. Keadaan ini justru membuat integrasi masyarakat semakin kuat karena terjadi ketergantungan sosial satu sama lain. Tujuan dari penelitian ini adalah untuk mengetahui pola integrasi dan ketergantungan sosial antar suku dan agama di kecamatan Kotagajah sehingga dapat digunakan sebagai prototype penanggulangan konflik di daerah lain. Penelitian dilakukan dengan menggunakan pendekatan deskriptif kualitatif dengan teknik analisis data menggunakan Analysis Interactive Model dari Miles dan Huberman. Pola integrasi yang terjadi di kecamatan Kotagajah antara lain di bidang idiologi, dimana setiap masyarakat adat/ suku memiliki idiologi/ falsafah hidup yang bernilai karakter relatif sama, namun berbeda tata cara pelaksanaannya. Pada bidang politik, kedewasaan berdemokrasi sudah muncul dengan lunturnya politik suku dan keagamaan pada pemilu. Di bidang ekonomi, keterampilan hidup kesukuan yang diwariskan secara turun-temurun membuat kehidupan ekonomi masyarakat merata. Pada bidang sosial budaya, asimilasi dan akulturasi kebudayaan terjadi untuk dapat saling menyesuaikan kehidupan sosialkemasyarakatan.
\end{abstract}

Keywords: Integrasi, Masyarakat Majemuk 


\begin{abstract}
The tribal and religious diversity in the Kotagajah have been forced the people to live together by bringing their different shari'a, local wisdom and culture respectively. This situation actually makes the community integration stronger because of social dependence on each other. Therefore, this research is intended to investigate the patterns of integration and social interdependence among tribes and religions in Kotagajah, therefore, it can be used as a prototype of conflict prevention in other area. The research was conducted by using qualitative - descriptive approach and analyzed by using Interactive Model Analysis from Miles and Huberman. The patterns of integration occurred in Kotagajah cover some aspects: in the ideology, in which every tribal / ethnic community has their ideology / philosophy of life that has the same relative character but it has been implemented in different ways. In the political, the democratic maturity has arisen with the decline of ethnic and religious politics in the elections. In economics, tribal life skills passed down from generation to generation make the economic life of society equally. Furthermore, in the socio-culture, assimilation and acculturation of culture occur in order to adjust each other in social life-society.
\end{abstract}

\title{
Keywords: Integration, Plural Society
}

\section{Pendahuluan}

Kecamatan Kotagajah merupakan salah satu gambaran masyarakat yang majemuk di provinsi Lampung khususnya di kabupaten Lampung Tengah. Walaupun memiliki perbedaanperbedaan yang nyata, namun dalam konteks hubungan kemasyarakatan antar komunitas itu hidup bersama dalam satukesatuan wilayah. Kemajemukan ini bermula saat pembukaan wilayah Kotagajah yang dahulunya merupakan hutan belantara dilakukan oleh 3 (tiga) kelompok masyarakat yang terdiri dari warga pribumi Lampung, Yayasan Pembuka Lahan (YAPETA), dan para transmigran yang telah berada di provinsi Lampung dari tahun 1932 (kolonisasi pada masa penjajahan Belanda) hingga masa Indonesia merdeka kisaran tahun 1970-an. Khusus untuk kelompok transmigran, mayoritas merupakan penduduk dari dari 
Tubagus Ali Rachman Puja Kesuma|

Jawa Barat (suku Sunda), Jawa Tengah, Jawa Timur, DIY Yogyakarta (suku Jawa) dan Bali (suku Bali) (Sabaruddin, 2013:17). Pembukaan lahan dilakukan masing-masing kelompok secara damai dan terorganisir walaupun berbeda prosedur dan tata caranya, sehingga walaupun terjadi konflik dapat diselesaikan dengan komunikasi yang baik dan musyawarah mufakat.

Sejak saat itu, Kotagajah merupakan sebuah desa/ kampung yang menjadi bagian dari kecamatan Punggur. Kampung ini diresmikan pada 12 januari 1974 melalui surat keputusan Bupati KDH Tingkat II lampung Tengah dengan No 23 Tahun 1973. Seiring perkembangan politik dan pemerintahan, Kotagajah memekarkan diri menjadi sebuah kecamatan pada tahun 2001, yang saat ini memiliki 7 kampung yaitu: Kotagajah, Kotagajah Timur, Sritejo Kencono, Saptomulyo, Nambahrejo, Sumberrejo, dan Purworejo. Letaknya yang strategis antara kota Metro, kota Gunung Sugih dan dan kota Sukadana membuat wilayah ini berkembang dengan pesat. Ditunjang tanah yang subur serta didukung adanya irigasi yang menjamin ketersediaan air untuk keperluan pertanian sepanjang tahun, kian menjadikan ini menjadi destinasi rantauan masyarakat sehingga tidak heran jika saat ini masyarakat kecamatan kotagajah menjadi masyarakat yang beragam. Keberagaman suku dan agama di kecamatan Kotagajah dapat dijabarkan dalam gambar berikut:

Gambar 1. Pemetaan persebaran suku kecamatan Kotagajah dan sekitarnya 


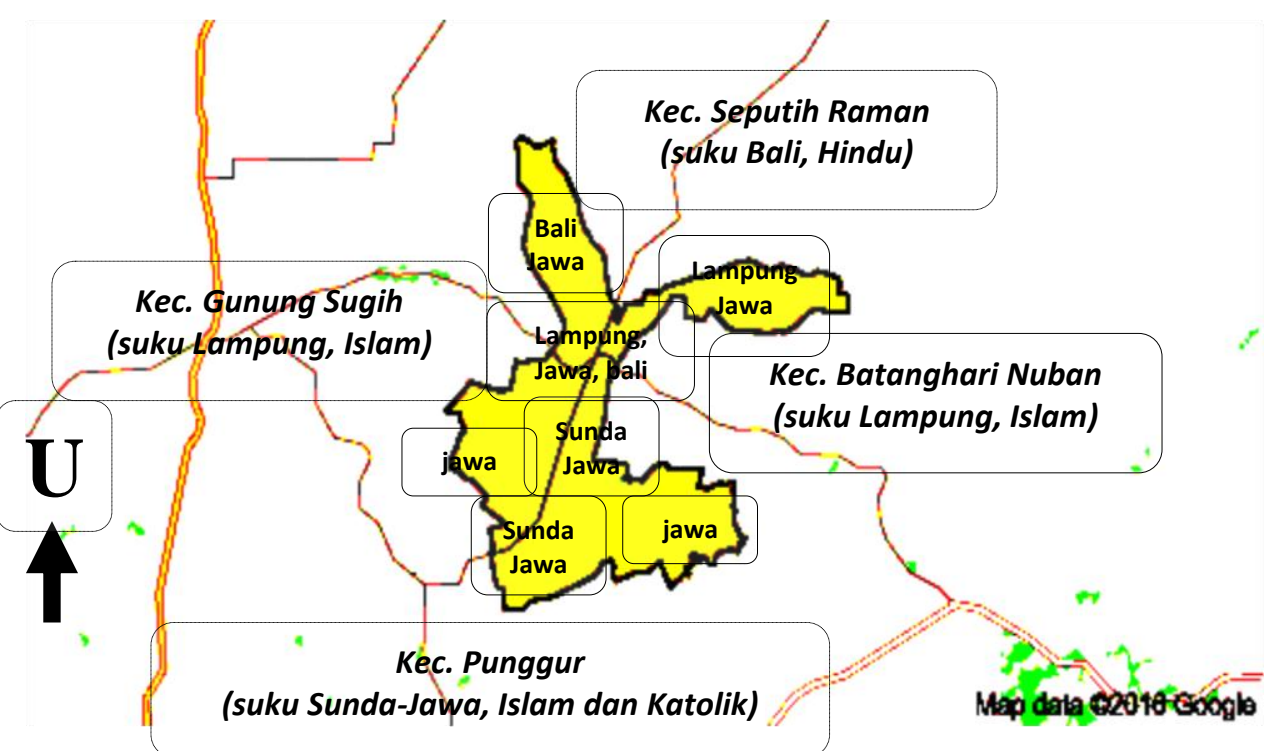

Sumber: https://www.google.co.id/maps/place/Kota+Gajah diakses tanggal 19 April 2016

Gambar tersebut menjelaskan keanekaragaman masyarakat kecamatan Kotagajah dengan mayoritas bersuku Jawa dan beragama Islam. Keadaan yang demikian membuat kehidupan bermasyarakat di kecamatan Kotagajah tidak terelakkan berinteraksi dengan antar suku dan agama. Terlebih, suku Lampung memiliki basis masyarakat di kecamatan Gunung Sugih dan kecamatan Kedaton yang mayoritas beragama Islam serta suku Bali memiliki basis masyarakat di kecamatan Seputih Raman dan Seputih Banyak yang mayoritas beragama Hindu.

Secara umum, beberapa wilayah di provinsi Lampung termasuk kabupaten Lampung Tengah memiliki riwayat konflik yang panjang dengan memiliki karateristik kemajemukan suku, agama, dan ras yang mirip dengan kecamatan Kotagajah. Konflik tersebut antara lain: 
Tubagus Ali Rachman Puja Kesuma|

Tabel 1. Riwayat Konflik di Provinsi Lampung Dalam Kurun Waktu 2010-2016

\begin{tabular}{|c|c|c|c|}
\hline No & Wilayah Konflik & $\begin{array}{c}\text { Waktu } \\
\text { Terjadinya }\end{array}$ & Keterangan Konflik \\
\hline 1. & $\begin{array}{l}\text { Register } 45 \text { dan } \\
\text { Alpha } 8 \\
\text { Kabupaten } \\
\text { Mesuji }\end{array}$ & $\begin{array}{c}6 \\
\text { November } \\
2010- \\
2016\end{array}$ & $\begin{array}{l}\text { suku pendatang (Jawa, Bali, } \\
\text { Bugis) yang merambah } \\
\text { hutan produksi dengan } \\
\text { Pamswakarsa (suku } \\
\text { Lampung) yang dibentuk PT } \\
\text { Silva Inhutani dan PT BSMI }\end{array}$ \\
\hline 2 & $\begin{array}{l}\text { Bekri, Kabupaten } \\
\text { Lampung Tengah }\end{array}$ & $\begin{array}{c}8 \text { Oktober } \\
2012\end{array}$ & $\begin{array}{l}\text { suku Jawa dengan suku } \\
\text { Lampung sebagai akibat } \\
\text { eigen righting (main hakim } \\
\text { sendiri) pelaku tindak } \\
\text { pidana pencurian }\end{array}$ \\
\hline 3 & $\begin{array}{l}\text { Padang Ratu, } \\
\text { Kabupaten } \\
\text { Lampung Tengah }\end{array}$ & $\begin{array}{l}24 \\
\text { Agustus } \\
2013\end{array}$ & $\begin{array}{l}\text { Suku Jawa dengan suku } \\
\text { Lampung sebagai akibat } \\
\text { eigen righting (main hakim } \\
\text { sendiri) pelaku tindak } \\
\text { pidana pencurian }\end{array}$ \\
\hline 4 & $\begin{array}{l}\text { Balinuraga, } \\
\text { Kabupaten } \\
\text { Lampung Selatan }\end{array}$ & $\begin{array}{c}27-29 \\
\text { Oktober } \\
2013\end{array}$ & $\begin{array}{l}\text { Suku Lampung, Banten dan } \\
\text { Jawa dengan Suku Bali } \\
\text { sebagai akibat dugaan } \\
\text { pelecehan seksual yang } \\
\text { meluas pada sentimen } \\
\text { keagamaan }\end{array}$ \\
\hline 5 & $\begin{array}{l}\text { Bumi Nabung, } \\
\text { Kabupaten } \\
\text { Lampung Tengah }\end{array}$ & $\begin{array}{l}23-24 \\
\text { Februari } \\
2014\end{array}$ & Sengketa lahan antar warga \\
\hline 6 & $\begin{array}{l}\text { Semaka, } \\
\text { Kabupaten } \\
\text { Tanggamus }\end{array}$ & $\begin{array}{l}30 \text { Juli } \\
2014\end{array}$ & $\begin{array}{l}\text { Suku Jawa dengan suku } \\
\text { Lampung sebagai akibat } \\
\text { tindakan eigen righting } \\
\text { (main hakim sendiri) pelaku } \\
\text { tindak pidana pencurian }\end{array}$ \\
\hline 7 & $\begin{array}{l}\text { Padang Ratu, } \\
\text { Kabupaten } \\
\text { Lampung Tengah }\end{array}$ & $\begin{array}{c}27 \\
\text { November } \\
2014\end{array}$ & $\begin{array}{l}\text { Kesenjangan sosial- } \\
\text { ekonomi, prasangka sosial, } \\
\text { dan eigen righting (main } \\
\text { hakim sendiri) pelaku } \\
\text { tindak pidana pencurian }\end{array}$ \\
\hline 8. & $\begin{array}{l}\text { Bunga Mayang, } \\
\text { Kabupaten } \\
\text { Lampung Utara }\end{array}$ & $\begin{array}{l}2 \text { Februari } \\
2016\end{array}$ & $\begin{array}{l}\text { Suku Jawa dengan suku } \\
\text { Lampung sebagai akibat } \\
\text { tindak pidana pembunuhan }\end{array}$ \\
\hline 9. & $\begin{array}{l}\text { Gunung Terang, } \\
\text { Kabupaten }\end{array}$ & $\begin{array}{l}11 \text { Maret } \\
2016\end{array}$ & $\begin{array}{l}\text { Suku Jawa dengan suku } \\
\text { Lampung sebagai akibat }\end{array}$ \\
\hline
\end{tabular}


JIPSINDO No. 2, Volume 4, September 2017

\begin{tabular}{|c|c|c|c|}
\hline & $\begin{array}{l}\text { Tulang Bawang } \\
\text { Barat }\end{array}$ & & tindak pidana pembunuhan \\
\hline 10. & $\begin{array}{l}\text { Hutan Tanam } \\
\text { Industri (HTI), } \\
\text { Kabupaten } \\
\text { Tulang Bawang } \\
\text { Barat }\end{array}$ & $2010-2016$ & $\begin{array}{l}\text { Perebutan lahan yang } \\
\text { meluas pada sentimen } \\
\text { kesukuan }\end{array}$ \\
\hline
\end{tabular}

Sumber: analisis pemberitaan media cetak dan elektronik

Intensitas konflik dan potensi laten yang tinggi di provinsi Lampung menempatkannya sebagai salah satu dari tiga daerah yang rawan konflik di Indonesia setelah Papua dan Maluku (http://regional.kompas.com/read/2015/02/09/1721466 diakses 18 April 2016). Berdasarkan pemetaan keberagaman suku dan agama riwayat konflik di provinsi Lampung tersebut, kecamatan Kotagajah dan sekitarnya hakekatnya termasuk dalam zona merah konflik di Lampung Tengah sebagai akibat kemajemukan suku dan agama masyarakatnya.

Konflik yang disertai kontak fisik sebagaimana terjadi di provinsi Lampung dapat beraneka ragam bentuk dan menyebar dalam segala aspek kehidupan masyarakat (ekonomi, politik, sosial-budaya, dan agama) sehingga mengganggu integrasi sosial. Keadaan ini biasanya dipicu rawannya kesenjangan, kecemburuan dan dendam sosial sehingga menimbulkan prasangka sosial yang memantik persinggungan kepentingan kelompok SARA. Prasangka sosial sendiri terjadi karena: antar kelompok masyarakat (suku) tidak memahami watak dan pola hidupnya, tidak adanya pola ketergantungan sosial (baik perseorangan atau golongan), tidak ada kesadaran akan dampak negatif dari prasangka sosial itu sendiri (Gerungan, 1988: 175).

Pada kenyataannya kecamatan Kotagajah merupakan wilayah yang kondusif bila di bandingkan wilayah lainnya di kabupaten Lampung Tengah yang memiliki karateristik keberagaman SARA 
Tubagus Ali Rachman Puja Kesuma|

yang sama. Dinamika sosial di kecamatan Kotagajah yang terjadi secara kontinyu justru menjelma menjadi suatu ikatan rasa kesatuan sosial. Konflik sebagai bagian dari dinamika sosial di kecamatan Kotagajah terjadi secara paradoks, dimana pada satu sisi konflik memang merupakan hal yang buruk dan dapat menimbulkan kerugian. Tetapi disisi lain konflik merupakan proses peleburan nilai, norma, adat, dan budaya masyarakat yang memperkokoh nilai-nilai kebhinekaan. Proses ini dapat berupa asimilasi dan atau akulturasi, keduanya akan menjadi pemicu terciptanya integrasi masyarakat yang kritis, kreatif dan maju (Robbins, 1996: 431). Keadaan ini baik secara langsung maupun tidak langsung berkontribusi terhadap ketahanan sosial kecamatan Kotagajah yang mendorong pembangunan di wilayah tersebut.

Pembauran kehidupan ekonomi, politik, sosial-budaya, dan beragama yang harmonis di kecamatan Kotagajah merupakan bukti terelakkannya ancaman, tantangan, hambatan dan gangguan (ATHG) ketahanan wilayah tersebut. Keberagaman di kecamatan Kotagajah justru menciptakan keadilan (justice) dimana antar suku akan merasa satu kesatuan yang utuh, kewajaran (equity) yang menjunjung tinggi toleransi, persamaan hak (equality) dimana semua orang dipandang sama tanpa memandang perbedaan SARA, dan kekuasaan (power) yang bertanggung jawab pada masyarakat luas dan tidak mementingkan golongan suku, agama, atau ras tertentu (Kabanoff sebagaimana dibahas Wirawan, 2013: 33).

\section{Masyarakat Majemuk}

Masyarakat majemuk memiliki karateristik yang ketat tidak dapat disamakan dengan masyarakat yang memiliki unit-unit kekerabatan yang bersifat segmenter. Menurut Nasikun (2006: 43), 
JIPSINDO No. 2, Volume 4, September 2017

pada masyarakat majemuk paling tidak harus terdiri dari dua komunitas, golongan atau kelompok-kelompok yang memiliki perbedaan secara kultural, ekonomi, agama dan politik serta memiliki tata aturan kelembagaan yang berbeda antara yang satu dan lainnya. Oleh karena itu, Pierre sebagaimana di bahas Nasikun menggolongkan ciri-ciri masyarakat majemuk antara lain

a. Terjadinya segmentasi golongan, dimana setiap golongan memiliki tata adat dan budaya yang berbeda satu sama lain.

b. Memiliki struktur sosial yang berdiri sendiri dan tidak saling melengkapi satu sama lain.

c. Tidak mencari pembenaran atas adat dan budayanya sehingga bersifat toleran satu dengan yang lain.

d. Walaupun kecil, konflik sering terjadi sebagai akibat persinggungan kepentingan.

e. Perlu adanya paksaan untu mewujudkan integrasi.

f. Biasanya terjadi saling ketergantungan di dalam bidang ekonomi.

Kelompok atau golongan yang memiliki basis massa paling besar cenderung mendominasi kelompok-kelompok yang lain. tingkat perbedaan yang tinggi. Adapun kemajemukan masyarakat Lampung Khususnya di kecamatan Kotagajah dan sekitarnya didasarkan pada ras, suku bangsa, agama, bahasa, profesi, dan budaya.

\section{Interaksi Sosial}

Interaksi sosial merupakan hubungan sebab akibat dan saling mempengaruhi satu sama lain secara kontinyu baik itu dalam konteks perorangan atau kelompok. Hubungan saling mempengaruhi tersebut lambat laun akan membentuk struktur 
Tubagus Ali Rachman Puja Kesuma|

sosial yang menjadi penegas identitas dan kontrol sosial di masyarakat.

Siagian (2004:216), secara positif interaksi sosial hanya mungkin terjadi apabila terdapat suasana saling mempercayai, menghargai, dan saling mendukung. Terjadinya kontak sosial dimana secara fisik subjek yang akan berinteraksi bertemu merupakan wujud dari rasa kepercayaan dan menghargai. Kemudian munculnya komunikasi dalam kontak sosial tersebut juga merupakan wujud dari rasa saling menghargai dan mendukung. Interaksi sosial bersifat dinamis yang menyesuaikan dengan kebutuhan subjek manusianya.

Interaksi sosial merupakan syarat agar integrasi berjalan dengan baik, adapun syarat terjadinya interaksi sosial menurut Abdulsyani (2007: 153) antara lain :

a) kontak sosial (social contact), yaitu adanya pertemuan jasmaniah antar subjek masyarakat sebagai bentuk niatan untuk berkomunikasi. Kontak sosial ini bisa saja terjadi antar individu, antar kelompok, ataupun individu dengan kelompok.

b) komunikasi (communication), yaitu penyampaian ekspresi, mimik, bahasa inderawi yang memberi arti pada perilaku orang lain serta mengungkapkan pendapat atau ide yang ingin disampaikan oleh orang tersebut, begitu pula sebaliknya.

Alur terjadinya interaksi sosial adalah dimulai dengan kerja sama (cooperation) untuk dapat saling memenuhi kebutuhan kemudian antar indivisu saling berlomba untuk memenuhi kebutuhan tersebut sehingga terciptalah persaingan (competition), apabila persaingan yang terjadi tidak sehat dan saling menjatuhkan satu sama lain apalagi sampai terjadi kontak fisik 
maka itu telah sampai pada tahap pertikaian (conflict), dan yang terakhir adalah proses meredam konflik yang disebut dengan akomodasi (accommodation). Siklus ini akan terus kembali berulang walaupun dalam jangka waktu yang relative lama (Wulansari, 2009: 32).

\section{Integrasi Sosial dan Konflik}

Integrasi dan konflik merupakan dua proses yang saling bertentangan namun sangat erat kaitannya satu sama lain, integrasi merujuk pada arah persatuan sedangkan sebaliknya konflik merujuk pada arah perpecahan. Integrasi terjadi bila interaksi sosial dimasyarakat menjelma menjadi suatu pola ketergantungan antar kelompok/ golongan dalam masyarakat, Sebagai contoh dalam bidang ekonomi, apabila semakin kecil ketergantungan ekonomi antar kelompok masyarakat, maka akan semakin besar potensi konflik yang terjadi.

Pola ketergantungan ini juga harus diimbangi rasa saling tulus dan ikhlas bertoleransi terhadap perbedaan yang ada, karena apabila toleransi diabaikan maka yang terjadi adalah sebaliknya yaitu konflik. Toleransi akan mencegah prasangkaprasangka sosial antar kelompok yang berkepanjangan dan berlarut-larut tanpa disertai pembuktian yang riil. Tidak ada batas pasti sampai dimana toleransi itu dapat dilaksanakan, yang jelas bahwa toleransi akan hancur oleh akumulasi konflik-konflik sederhana yang semakin membawa corak kelompok/ golongan.

Menurut Maryati dkk (2006: 70), integrasi sosial dapat terjadi melalui beberapa proses-proses antara lain :

a) Asimilasi (assimilation), merupakan proses sosial untuk mengurangi perbedaan-perbedaan sosial di masyarakat. Adapun faktor yang mempengaruhi antara lain:

a. Adanya toleransi melalui proses akomodasi. 
Tubagus Ali Rachman Puja Kesuma|

b. Adanya pengakuan yang sama.

c. Adanya sikap saling menghargai antar individu atau kelompok lain.

d. Adanya sikap terbuka.

b) Akulturasi, merupakan proses terintegrasinya unsure kebudayaan asing tanpa mengakibatkan hilangnya kepribadian kebudayaan itu sendiri. Kebudayaan asing akan relatif dapat di terima apabila memenuhi syarat-syarat sebagai berikut :

1. Tidak ada hambatan geografis yang mengurangi intensitas interaksi sosial.

2. Kebermanfaatan kebudayaan asing

3. Adanya persamaan unsur-unsur kebudayaan lama

4. Adanya kesiapan pengetahuan dan ketrampilan tertentu

5. Kebudayaan itu bersifat kebendaan

Proses integrasi membutuhkan pengakuan hak dan kewajiban yang seimbang, sehingga antar individu atau kelompok bisa saling menerima perbedaan dengan penuh kesadaran dan keikhlasan untuk menyamakan tujuan hidup bermasyarakat. Apabila hal itu diabaikan maka konfliklah yang akan terjadi. Konflik merupakan kebalikan dari proses integrasi, hal ini terjadi karena terjadinya pertentangan dan persinggungan pihak-pihak yang berkepentingan. Dalam berbagai kasus konflik SARA khususnya di provinsi Lampung, sering kali ditekankan bahwa penyebab pertentangan dan persinggungan itu dikarenakan perbedaan tingkatan ekonomi, pola pikir dan pola perilaku.

\section{Pola Ketergantungan/ Interdependensi sosial}

Proses pemenuhan membutuhkan manusia yang terjadi dalam jangka waktu yang lama akan memicu proses 194 
JIPSINDO No. 2, Volume 4, September 2017

ketergantungan sosial baik secara individu maupun kelompok. Dalam proses ini setiap individu atau kelompok masyarakat akan terkodefikasi tentang keahlian pemenuhan kebutuhannya masingmasing yang dijadikan nilai jual terhadap pemenuhan kebutuhannya yang lain. Pemenuhan kebutuhan antar masyarakat yang memiliki kodefikasi keahliannya tersebut secara alami akan membentuk suatu pola interdependensi sosial yang dapat memicu terjadinya konflik dan atau integrasi. Menurut Wirawan (2013: 9), pola ketergantungan sosial tersebut antara lain:

a) Ketergantungan pol (pooled interdependence)

Merupakan bentuk ketergantungan bertingkat (hierarki) antara atasan dan bawahan. Atasan membutuhkan bawahan untuk membantu kinerjanya, sedangkan bawahan membutuhkan atasan untuk kelangsungan karier yang berimbas pada pemenuhan kebutuhan hidupnya. Jumlah bawahan yang setara akan lebih banyak dan saling berkompetisi menjadi yang terbaik.

b) Ketergantungan urutan (sequential interdependence) Merupakan suatu bentuk ketergantungan yang setara dan saling melengkapi dan mengisi antara satu dengan yang lain, namun tidak bisa dipertukarkan. Misalnya, ketergantungan antara penjual bibit sayur, penjual pupuk, petani sayur, tengkulak dan pedagang sayur.

c) Ketergantungan timbal balik (reciprocal interdependence) Merupakan suatu bentuk ketergantungan yang setara dan saling melengkapi dan mengisi antara satu dengan yang lain, yang bisa dipertukarkan. Misalnya, praktik dokter dan apotik, penjual kain dan penjahit, dll. 
Tubagus Ali Rachman Puja Kesuma|

Ketiga bentuk ketergantungan/ interdependensi sosial tersebut memiliki konsekuensi yang berbeda. Walaupun saling membutuhkan, bentuk ketergantungan pol lebih mengarah pada konflik karena kerjasama hanya dominan terjadi pada hirarki atasan dan bawahan. Sedangkan persaingan-persaingan dibawah yang jumlahnya lebih besar sangat rentan konflik kepentingan. Bentuk ketergantungan urutan dan timbal balik lebih mengarah pada integrasi karena adanya rasa kerja sama yang saling menguntungkan, dan dengan begitu mereka akan saling menjaga perbedaan diantara mereka.

\section{Metode Penelitian}

Penelitian ini dilakukan dengan menggunakan pendekatan deskriptif kualitatif dengan mengeksplorasi ketergantungan suatu kelompok/ golongan terhadap sektor kehidupan kelompok/ golongan yang lain melalui batasan terperinci, pengambilan data terhadap sumber informasi dilakukan langsung secara mendalam. Pencarian dan pengambilan data difokuskan pada data kualitatif dengan cara penelitian lapangan dan kepustakaan. Di lapangan metode pengumpulan data dilakukan dengan kegiatan wawancara, observasi, dan dokumentasi. Analisis data dalam penelitian ini menggunakan Analysis Interactive Model dari Miles dan Huberman.

Gambar 2. Analisis data model interaktif.

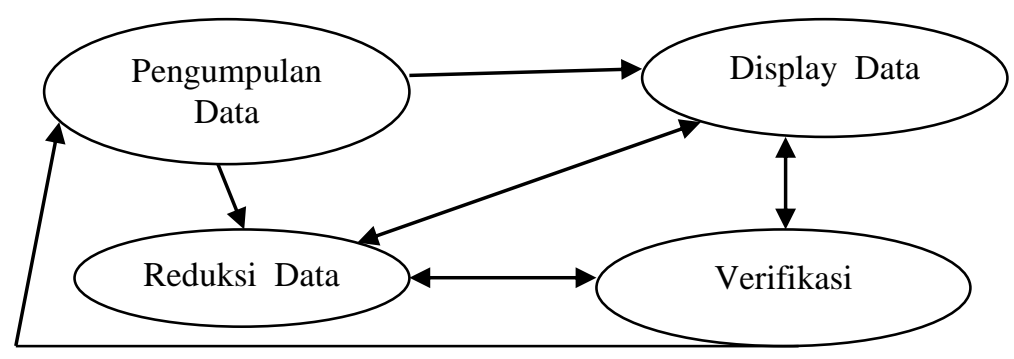

Sumber: Miles and Huberman (1992: 20) 
Model analisis interaktif yang telah dikembangkan oleh Miles dan Huberman tersebut dilakukan untuk menilai keabsahan data dan pengerucutan atas jawaban pertanyaan penelitian. Populasi merupakan seluruh masyarakat kecamatan Kotagajah yang berjumlah 33.051 jiwa (BPS Kabupaten Lampung Tengah, 2015: 41), yang tersebar di 7 Kampung. Sampel penelitian ditentukan secara terpilih dan dengan teknik snowball sampling yang meliputi: aparatur pemerintahan kecamatan, tokoh masyarakat (Suku Jawa, Lampung, Bali, dan Sunda), masyarakat yang menjadi praktisi kegiatan sosial ekonomi (petani dan pedagang), dan aparat kepolisian.

\section{Hasil Penelitian dan Pembahasan}

\section{Pola Integrasi Masyarakat Majemuk di Kecamatan Kotagajah Bidang Idiologi}

Setiap suku memiliki falsafah hidup yang bersumber dari kearifan lokal yang nilai-nilainya diakui oleh masyarakat adatnya. Falsafah hidup masyarakat ini merupakan idiologi tradisional sebagai hasil kebudayaan suatu masyarakat yang telah hidup bersama dalam jangka waktu yang lama. Kearifan lokal ini dibelajarkan secara turun temurun dan memuat sejumlah dasar dan aturan/ hak dan kewajiban untuk ditaati masyarakat didalamnya. Walaupun bersifat intern, namun dalam kehidupan masyarakat yang majemuk dan agama, falsafah ini dapat menjadi dasar integrasi sosial di masyarakat yang majemuk. Karena pada hakekatnya setiap pedoman hidup antar suku mengajarkan tentang nilai-nilai kebenaran dan kebaikan baik yang berlandaskan atas hukum agama maupun kebiasaan hidup bermasyarakat, namun dengan cara yang berbeda.

Orang Jawa memiliki pedoman hidup berupa Pitutur yang berupa wejangan bersajak. Nilai dalam Pitutur inilah yang 
Tubagus Ali Rachman Puja Kesuma|

dijadikan pedoman hidup orang Jawa. Pitutur jawa ini memiliki persamaan nilai dengan Piil Pesenggirinya orang Lampung", Trihita Karana orang Bali, dan Tri Tangtu orang Sunda (Rudiyanto.HW.TMJ/5/NS.5 tanggal 28 Juli 2016).

Setidaknya terdapat sepuluh sajak pitutur ini yang familiar didengar dalam kehidupan masyarakat Jawa. Kesepuluh Pitutur itu antara lain:

1) Urip iku urup. Artinya hidup itu harus seperti api (penerangan), menyala dan memberikan penerangan (kebermanfaatan) bagi sesama.

2) Guyub Agawe Sentosa. Artinya hidup rukun dan melakukan segala sesuatu dengan tolong menolong akan membuat suatu kesejahteraan bagi seluruh masyarakat.

3) Memayu hayuning bawono, ambrasto dur hangkoro. Artinya kehidupan manusia harus mengusahakan kesejahteraan, keselamatan dan kebahagiaan, namun semua itu tidak boleh dilandasi dengan hawa nafsu angkara murka.

4) Suro diro joyoningrat, lebur denging pangastuti. Artinya hawa nafsu angkara murka, keras hati, dan kelicikan tidak bisa/ boleh dibalas dengan hal yang sama.

5) Ngluruk tanpa bolo, menang tanpo ngasorakke, sekti tanpo aji-aji, sugih tanpo bondo. Artinya berjuang tanpa bantuan orang banyak (mandiri), menanggung segala akibat yang telah diperbuat diri sendiri dan tidak mengkambing hitamkan orang lain. Jika senang/ menang tanpa mempermalukan, mengolok-olok dan merendahkan orang lain, berwibawa tanpa mengandalkan kekuatan, kekayaan atau kekuasaan.

6) Datan serik lamun ketaman, datan susah lamu kelangan. Artinya jangan sakit hati kala musibah datang, jangan mudah menyerah bila menemui kegagalan, jangan sedih 
kala kehilangan, dan tetap bersyukur atas kenikmatan yang diberikan Allah Subhanahu Wa Ta'ala, Tuhan Yang Maha Esa.

7) Ojo gumunan, ojo getunan, ojo kagetan, lan ojo aleman. Artinya jangan gampang terheran-heran atas sesuatu hal yang bukan menjadi haknya, jangan mudah menyesal atas segala sesuatu yang ditakdirkan Allah Subhanahu Wa Ta'ala, Tuhan Yang Maha Esa. Jangan mudah terkejut atas kelebihan dan kekurangan orang lain, dan jangan mudah manja atas apa yang telah dimiliki.

8) Ojo ketungkul marang kalungguhan, kadonyan lan kemareman. Artinya jangan terlalu terobsesi atas godaan duniawi (harta, tahta dan wanita) dan kepuasan duniawi lainnya.

9) Ojo kuminter mundak keblinger, ojo cidro mundak ciloko. Artinya jangan merasa pinter dan cukup agar tidak berhenti belajar, dan jangan licik/ curang agar tidak celaka, karena karma itu selalu ada.

10) Ojo milik barang kang melok, ojo mangro mundak kendho. Artinya jangan tergiur oleh hal-hal yang nampak mewah, cantik atau indah, dan jangan mendua agar tidak mengganggu niat dan tujuan.

11) Ojo adigang, adigung, adiguna. Artinya jangan sok kuasa karena tinggi jabatan, banyak uang dan memiliki segalanya. Jangan sok besar hati atas apa yang telah diperbuat, karena apa yang kita perbuat belum tentu bermanfaat untuk orang lain. Dan jangan sok sakti atas ilmu yang dimiliki, karena tuntutan ilmu itu tidak akan pernah berhenti selama nyawamasih dikandung badan. 
Tubagus Ali Rachman Puja Kesuma|

Walaupun sebatas wejangan, pitutur ini memiliki sanksi sosial di masyarakat mulai dari celaan, dikucilkan hingga diasingkan. Selanjutnya, suku Lampung sendiri terikat oleh kearifan lokal berupa falsafah/ pandangan hidup Piil Pesenggiri yaitu falsafah hidup suku Lampung dalam menjalani hidup mereka yang tertuang dalam kitab Kuntjara Radja Niti yang merupakan warisan sejarah peradaban suku Lampung. Falsafah hidup Piil Pesenggiri pada masyarakat suku Lampung terdiri dari empat pilar utama yaitu:

1) Juluk-adok yang berarti bahwa selain memiliki nama secara umum, suku Lampung juga memiliki nama/gelar dalam kehidupan adatnya. Dalam pergaulan masyarakat adat sehari-hari, nama/ gelar adat itulah yang digunakan sebagai panggilan. Dalam memberikan Adek/ Adok, Suku Lampung memberikan nama-nama/ gelar adat kebesaran/ kebangsawanan yang bermakna baik/ positif dan diharapkan menjadi identitas utama yang melekat pada pribadi yang bersangkutan yang telah ditetapkan berdasarkan hirarki status keluarganya dalam struktur kepemimpinan adat. Juluk-adok merupakan asas identitas dan sebagai sumber motivasi bagi anggota suku Lampung untuk dapat menempatkan hak dan kewajibannya, kata dan perbuatannya dalam setiap perilaku dan karyanya.

2) Nemui-nyimah yang berarti bahwa suku Lampung sangat gemar bersilaturahmi dan menerima tamu dengan baik. Bahkan suatu keharusan bagi mereka untuk memperlakukan tamu dengan sangat baik, karena seorang tamu yang berkunjung kerumah merupakan suatu kehormatan dan penghargaan yang harus dibalas dengan sebuah kehormatan pula. 
3) Nengah-nyampur yang berarti bahwa suku Lampung sangat membuka diri dalam pergaulan sehari-hari. Mereka juga tidak segan untuk mengangkat saudara (Angkon Muakhi), untuk menunjukan ketulusan mereka dalam bergaul.

4) Sakai-sambaian yang berarti bahwa suku Lampung suka bergotong-royong dan saling membantu dengan anggota masyarakat lainnya.

Suku Lampung memang terkenal kasar dengan nada/ intonasi bicara yang tinggi, namun itu yang menjadi watak/ karakter mereka layaknya suku di wilayah sumatera lainnya. Walaupun demikian mereka memiliki budaya dan tradisi yang baik dan sangat menerima pendatang. Dari falsafah hidup mereka juga dapat diketahui bahwa pada hakekatnya mereka cinta damai, toleran, dan senang bergaul. Suku Sunda memiliki falsafah hidup Tri Tangtu, adapun falsafah ini setidaknya terdiri dari:

1) Gusti anu asih, alam anu ngasah, manusa anu ngasuh (silih asah, silih asih, silih asuh) yang artinya bahwa Allah Subhanahu Wa Ta'ala, Tuhan Yang Maha Kuasa yang maha mengasihi manusia dengan memberikan segala kenikmatan dan kebutuhannya. Alam yang mengasah kehidupan manusia yang dalam rangka memenuhi kebutuhannya manusia harus memanfaatkan alam disekitarnya. Hal ini, membuat manusia harus mengasah pikiran sebagai salah satu anugerah Allah Subhanahu Wa Ta'ala, Tuhan Yang Maha Kuasa dalam memanfaatkannya. Manusia harus pandai-pandai bersyukur atas nikmat dari Allah Subhanahu Wa Ta'ala, Tuhan Yang Maha Kuasa serta memelihara alam sekitarnya agar dapat terus dimanfaatkan dan tidak menjadi musibah. 
Tubagus Ali Rachman Puja Kesuma|

2) Wenang, Kala, Wening yang artinya bahwa segala sesuatu hanya dimiliki Allah Subhanahu Wa Ta'ala, Tuhan Yang Maha Kuasa, dan apapun yang terjadi dalam kehidupan ini adalah kehendak-Nya, oleh karena itu sebagai manusia kita harus bertauhid atas segala ketetapan-Nya.

3) Resi, rama, raja yang artinya berlaku sederhana dengan memiliki niat dan tekad yang teguh, mempunyai idealisme dalam memperjuangkan kebenaran, dan mampu menjaga wibawa serta amanah atas kekuasaan yang dimilikinya.

4) Naluri, nurani, nalar yang artinya menyelaraskan apa yang dipikirkan, dirasakan, dan dilaksanakan.

5) Dasa kerta, Dasa Prebakti, yang artinya bahwa kesejahteraan hidup dapat dicapai dengan menjaga sepuluh bagian tubuh manusia dan menggunakan kedudukan, jabatan dan kekuasaannya untuk kebermanfaatan kepada orang lain.

6) Panca aksara, guruning janma yang artinya pengalaman harus dijadikan pelajaran kehidupan, dan jangan terjerebak dalam kesalahan/ kegagalan yang sama

7) Ngawakan tapa di nagara yang artinya seseorang harus memiliki kemampuan atau keahlian. Akal pikiran, perasaan harus mampu menumbuhkan semangat kreatifitas untuk menciptakan sesuatu yang memiliki daya guna, daya beli, daya saing serta berguna bagi orang lain.

Falsafah ini menunjukan bahwa orang Sunda berpedoman pada apa yang telah ditentukan dari Gusti Nu Murbeg Alam (Allah Subhanahu Wa Ta'ala, Tuhan Yang Maha Kuasa). Ketaatan kepada-Nya menjadi suatu hal yang mutlak harus dilaksanakan, karena semua bersumber dan akan kembali hanya pada-Nya. Suku Bali memiliki falsafah hidup Trihita Karana, Hal ini 
JIPSINDO No. 2, Volume 4, September 2017

bermakna bahwa sumber kebahagiaan hidup masyarakat Bali terdiri dari tiga hal yaitu:

1) Parahyangan yang artinya hubungan manusia dengan Sang Hyang Widi Wasa (Tuhan Yang Maha Kuasa). Karena sebagala sesuatu berjalan atas ketetapan dan izin-Nya.

2) Palemahan yang artinya hubungan manusia dengan alam. Alam harus tetap dijaga agar tetap lestari karena menjadi sumber penghidupan bagi manusia

3) Pawongan yang artinya hubungan manusia dengan sesama. Sesuai sifat dasar manusia yang tidakbisa hidup sendiri tanpa bantuan dari orang lain, maka antar manusia harus saling menghargai dan menghormati satu dengan lainnya.

Nilai Trihita Karana bersumber pada dharma manusia sebagai ciptaan Sang Hyang Widhi Wasa, Tuhan Yang Maha Esa sehingga harus beriman kepada-Nya, menghargai dan menjaga sesama ciptaannya, dan saling bantu-membantu dan bertoleransi dengan sesama manusia. Semua falsafah hidup masyarakat di kecamatan Kotagajah yang majemuk tersebut memiliki keterkaitan dan keterdukungan satu sama lain. Hal tersebut dijabarkan dalam tabel berikut:

Tabel 3. Keterkaitan dan Keterdukungan Nilai Karakter Idiologi Kesukuan

\begin{tabular}{lllll}
\hline $\begin{array}{c}\text { Piil } \\
\begin{array}{c}\text { Peseng } \\
\text { giri }\end{array}\end{array}$ & \multicolumn{1}{c}{ Pitutur } & Tri Tangtu & $\begin{array}{l}\text { Trihita } \\
\text { Karana }\end{array}$ & Karakter* \\
\hline 1. & 1. Urip iku urup & 1. Wenang, & 1. Parahyan & 1) Cinta \\
Bejuluk- & 2. Memayu & Kala, & gan & Tuhan dan \\
Beadek/ & hayuning & Wening & 2. Palemaha & segenap \\
Juluk- & bawono, & 2. Resi, rama, & $n$ & ciptaan- \\
Adok & ambrasto dur & raja & 3. Pawonga & Nya \\
& hangkoro & 3. Dasa kerta, & $n$ & 2) Kemandiri \\
& 3. Suro diro joyo & Dasa & & an dan \\
\hline
\end{tabular}


Tubagus Ali Rachman Puja Kesuma|

\begin{tabular}{|c|c|c|c|c|}
\hline & $\begin{array}{l}\text { joyoningrat, } \\
\text { lebur denging } \\
\text { pangastuti } \\
\text { 4. Ngluruk tanpa } \\
\text { bolo, menang } \\
\text { tanpo } \\
\text { ngasorakke, } \\
\text { sekti tanpo aji- } \\
\text { aji, sugih tanpo } \\
\text { bondo }\end{array}$ & Prebakti & & $\begin{array}{l}\text { tanggung } \\
\text { jawab } \\
\text { 3) Kejujuran } \\
\text { / amanah, } \\
\text { bijaksana } \\
\text { 4) Hormat } \\
\text { dan } \\
\text { santun } \\
\text { 5) Dermawan } \\
\text {, suka }\end{array}$ \\
\hline $\begin{array}{l}2 . \\
\text { Nemui- } \\
\text { Nyimah }\end{array}$ & $\begin{array}{l}\text { 1. Ojo gumunan, } \\
\text { ojo getunan, } \\
\text { ojo kagetan, } \\
\text { lan ojo aleman } \\
\text { 2. Ojo milik } \\
\text { barang kang } \\
\text { melok, ojo } \\
\text { mangro } \\
\text { mundak } \\
\text { kendho }\end{array}$ & $\begin{array}{l}\text { 1. silih asah, } \\
\text { silih asih, } \\
\text { silih asuh }\end{array}$ & $\begin{array}{l}\text { 1. Parahyan } \\
\text { gan } \\
\text { 2. Palemaha } \\
n \\
\text { 3. Palemaha } \\
n\end{array}$ & $\begin{array}{l}\text { menolong } \\
\text { dan gotong } \\
\text { royong } \\
\text { 6) Percaya } \\
\text { diri, } \\
\text { kreatif dan } \\
\text { pekerja } \\
\text { keras } \\
\text { 7) Kepemimp } \\
\text { inan dan }\end{array}$ \\
\hline $\begin{array}{l}. \\
\text { Nengah- } \\
\text { Nyappur }\end{array}$ & $\begin{array}{l}\text { 1. Urip iku urup } \\
\text { 2. Datan serik } \\
\text { lamun } \\
\text { ketaman, datan. } \\
\text { susah lamu } \\
\text { kelangan. } \\
\text { 3. Ojo adigang, } \\
\text { adigung, } \\
\text { adiguna }\end{array}$ & $\begin{array}{l}\text { 1. silih asah, } \\
\text { silih asih, } \\
\text { silih asuh } \\
\text { 2. Naluri, } \\
\text { nurani, } \\
\text { nalar } \\
\text { 3. Panca } \\
\text { aksara, } \\
\text { guruning } \\
\text { janma }\end{array}$ & $\begin{array}{l}\text { 1. Parahyan } \\
\text { gan } \\
\text { 2. Palemaha } \\
\text { n } \\
\text { 3. Palemaha } \\
n\end{array}$ & $\begin{array}{l}\text { keadilan } \\
\text { 8) Baik dan } \\
\text { rendah } \\
\text { hati } \\
\text { 9) Toleransi, } \\
\text { kedamaian } \\
\text { dan } \\
\text { kesatuan }\end{array}$ \\
\hline $\begin{array}{l}4 . \\
\text { Sakai- } \\
\text { Sambay } \\
\text { an }\end{array}$ & $\begin{array}{l}\text { 1. Urip iku urup } \\
\text { 2. Ojo kuminter } \\
\text { mundak } \\
\text { keblinger, ojo } \\
\text { cidro mundak } \\
\text { ciloko }\end{array}$ & $\begin{array}{l}\text { 1. silih asah, } \\
\text { silih asih, } \\
\text { silih asuh } \\
\text { 2. Ngawakan } \\
\text { tapa di } \\
\text { nagara }\end{array}$ & $\begin{array}{l}\text { 1. Parahyan } \\
\text { gan } \\
\text { 2. Palemaha } \\
n \\
\text { 3. Palemaha } \\
n\end{array}$ & \\
\hline
\end{tabular}

(IHF) (Kesuma, 2011: 8) 
Pada hakekatnya, falsafah hidup masing masing-masing suku ini memiliki persamaan nilai karakter yang menjadi acuan dalam mencapai cita-cita hidup bermasyarakat walaupun berbeda cara pelaksanaannya. Setiap masyarakat dalam suatu suku yang melakukan dan melestarikan falsafah hidup mereka, maka sejatinya mereka juga melakukan dan melestarikan nilai falsafah hidup suku yang lainnya, hal ini juga mengindikasikan antar masyarakat adat yang satu dengan yang lain memiliki tujuan dan cita-cita hidup yang sama.

\section{Bidang Politik}

Menilik masalah perpolitikan masyarakat di kecamatan Kotagajah merupakan suatu hal yang menarik, karena tentu akan melibatkan suku dan agama sebagai unsur primordial dan egosektoral yang sangat penting dalam penggalangan basis dukungan politik. Budaya politik masyarakat Kotagajah sudah tergolong partisipan dengan antusiame tinggi dalam berpolitik. Seorang aparatur pemerintahan pada wawancara pada 30 Juni 2016 memaparkan bahwa:

Politik suku dan agama berjalan dengan harmonis di kecamatan Kotagajah. Secara umum, lihat saja kepemimpinan bupati Pairin dan wakilnya Mustofa periode lalu, walaupun Pairin orang Jawa tapi bisa menjadi pemimpin di daerah Lampung Tengah, dan hal tersebut tidak menimbulkan kegaduhan politik atau aksi protes dari masyarakat yang bersuku Lampung. Begitu juga periode saat ini, Mustafa yang merupakan orang Lampung justru menang di Lampung Tengah yang di dominasi orang Jawa, dan suku pendatang lain pun juga tidak ada yang protes. (Dwi Haryono.HW.AP/3/NS.4 tanggal 30 Juni 2016)

Politik suku dan agama berjalan dengan harmonis seiring dengan maraknya perkawinan antar suku dan agama (amalgamasi). Keterbukaan masyarakat dalam hal perkawinan 
Tubagus Ali Rachman Puja Kesuma|

tersebut membuat ikatan kekerabatan menjadi luas dan melampaui batasan egosektoral suku dan agama. Amalgamasi juga membuat antar oknum masyarakat adat/ suku dan umat beragama akan dapat saling menjaga toleransi berpolitik karena ikatan perkawinan kerabat mereka akan menjadi pengaruh besar dalam berprasangka sosial dan men-justifikasi suku/ agama yang lainnya. Sebagai contoh Pairin yang notabene bersuku Jawa mampu menjadi Bupati dan dapat diterima oleh suku pribumi Lampung di kabupaten Lampung Tengah. Hal ini dikarenakan selain berpasangan dengan Mustafa yang bersuku Lampung sebagai wakil bupatinya, Pairin juga beristrikan seorang bersuku Lampung dan telah 'di-Lampung-kan' melalui serangkaian upacara adat (begawi) dan mempunyai gelar (adok/ adek) Rajo Perwira Pemangku Bumi Sai Wawai II. Gelar tersebut memberikan suatu makna bahwa yang bersangkutan telah dianggap sebagai bagian dari msyarakat suku Lampung serta memiliki hak dan kewajiban keadatan yang berlaku.

\section{Bidang Ekonomi}

Masyarakat antar suku saling berdampingan bahkan saling membutuhkan dalam melakukan kegiatan ekonominya. Kegiatan ekonomi masyarakat kecamatan Kotagajah tercermin dalam tabel berikut:

\section{Tabel 2. Sebaran Mata Pencaharian Bedasarkan Kesukuan}

\begin{tabular}{|c|c|c|c|c|}
\hline No & $\begin{array}{c}\text { Mata } \\
\text { Pencaharian }\end{array}$ & Prosentase & Spesifikasi & $\begin{array}{l}\text { Dominasi } \\
\text { Suku }\end{array}$ \\
\hline \multirow[t]{4}{*}{1.} & Petani & $64,26 \%$ & Persawahan & $\begin{array}{l}\text { Jawa, Bali dan } \\
\text { Sunda }\end{array}$ \\
\hline & & & Perladangan & $\begin{array}{l}\text { Jawa dan } \\
\text { Lampung }\end{array}$ \\
\hline & & & Perkebunan & Lampung \\
\hline & & & Peternak & $\begin{array}{l}\text { Jawa, Bali dan } \\
\text { Sunda }\end{array}$ \\
\hline
\end{tabular}


JIPSINDO No. 2, Volume 4, September 2017

\begin{tabular}{llll}
\hline 2. Pedagang & $25 \%$ & Hasil Bumi & $\begin{array}{l}\text { Jawa dan } \\
\text { Sunda } \\
\text { Perabot dan } \\
\end{array}$ \\
& & $\begin{array}{l}\text { Lampung } \\
\text { furniture } \\
\text { Sembako }\end{array}$ & Jawa \\
\hline 3. Lain-lain & 10,74 & $\begin{array}{l}\text { ASN } \\
\text { Wiraswasta }\end{array}$ & $\begin{array}{l}\text { Lampung, } \\
\text { Jawa, Bali dan } \\
\text { Sunda }\end{array}$ \\
\hline
\end{tabular}

Sumber: Monografi Kecamatan Semaka (2010)

Masing masing suku khususnya dalam pengelompokan pendatang (Jawa, Sunda, Bali) dan pribumi (Lampung) hakekatnya memiliki warisan keterampilan hidup yang berbeda satu sama lain, sehingga tidak berbenturan kepentingan. Suku Jawa dan Bali memiliki doktrinasi yang kuat dalam pertanian. Ketekunan dan keuletan serta kesabaran dalam menggarap lahan pertanian terutama bercocok tanam padi di areal persawahan, menjadikannya promotor supplay kebutuhan pokok beras dan hal tersebut teregenerasi turun-temurun. Kedekatan suku Jawa dan Bali yang notabene memiliki ikatan sejarah persaudaraan, terjalin melalui komunikasi dan interaksi sosial yang baik sehingga meminimalisir konflik dalam bidang ekonomi. Hasil pertanian suku Jawa dan Bali khususnya padi cukup memberikan kestabilan harga beras di pasaran khususnya di kecamatan Kotagajah pada kisaran Rp $7.000 / \mathrm{kg}$ untuk kualitas biasa, Rp. $8.000 / \mathrm{kg}$ untuk kualitas sedang dan Rp. 9.000-10.000/kg untuk kualitas baik. Hal ini menjadi cukup memberikan implikasi positif bagi suku pribumi Lampung yang membutuhkan beras sebagai kebutuhan pokok kehidupan namun tidak terbiasa dengan keterampilan hidup bersawah.

Di beberapa tempat/ wilayah di provinsi Lampung khususnya di kecamatan Kotagajah, suku Jawa merupakan motor penggerak pembangunan suatu daerah. Sebagai contoh adanya pasar sebagai tempat transaksi jual beli dengan bentuk persaingan terbuka 
Tubagus Ali Rachman Puja Kesuma|

merupakan wujud gerakan pembangunan suku Jawa. Dalam hal ini, jual beli yang dilakukan di pasar akan memungkinkan masyarakat suku lain (terutama pribumi Lampung) memperoleh penghasilan dari kegiatan perdagangan dan mendapatkan barang yang layak, murah dan mudah tanpa monopoli. Hasil bumi suku Lampung seperti kelapa, kopi, kakao yang sebelumnya dijual pada tengkulak dapat diperjual belikan langsung dipasar dengan harga yang jauh lebih tinggi.

Pada beberapa profesi, suku Jawa dan Sunda menjadi penghubungan kegiatan ekonomi antara suku Lampung dan Bali. Suku Bali yang mayoritas beragama Hindu memang kurang leluasa dalam pergaulan bermasyarakat dengan suku Lampung kerena memiliki perbedaan aturan hidup yang cukup mencolok dengan umat agama lain, dan masyarakat suku Lampung sendiri cukup fanatik menyikapinya. Contohnya adalah tersedianya pasokan daging sapi di wilayah kecamatan Kotagajah dan sekitarnya tidak lepas dari peranan masyarakat Jawa dan Sunda, khususnya yang berprofesi sebagai belantik sapi. Sapi-sapi mayoritas diperoleh dari masyarakat suku Bali di kecamatan Seputih Raman, Seputih Banyak hingga Gaya Baru. Sapi yang diperoleh dari wilayah ini adalah sapi merah atau sapi bali yang dewasa ini sangat diminati masyarakat suku Lampung untuk acara begawi pernikahan atau khitanan sebagai pelengkap/ pengganti daging kerbau yang semakin sulit dicari dan harganya mahal.

Masing-masing umat beragama saling berinteraksi dengan baik dalam bidang perekonomian baik melalui koperasi (simpan pinjam, gapoktan dan kelompok usaha masyarakat) maupun lembaga keuangan Bustanul Maal wa at-Tanwil yang boleh dimanfaatkan juga oleh masyarakat beragama lain. Umat Kristen 
JIPSINDO No. 2, Volume 4, September 2017

Katolik membangun eksistensinya dengan menyediakan layanan kesehatan klinik Mardi Waluyo yang melayani pertolongan pertama kesehatan masyarakat Kotagajah pada umumnya. Masyarakat yang beragama lain juga turut serta dalam mengembangkan pembangunan di kecamatan Kotagajah dengan kegiatan sosial dan profesinya masing-masing.

\section{Bidang Sosial-Budaya}

Sebagai wilayah dengan masyarakat yang majemuk, kecamatan Kotagajah memiliki adat kebudayaan yang beragam dan dilestarikan oleh masing-masing masyarakat adatnya. Beberapa diantaranya masih dipertahankan orisinalitasnya, dan beberapa diantaranya terasimilasi dan bahkan terakulturasi dengan adat dan budaya suku lain. Proses asimilasi dan akulturasi di kecamatan Kotagajah terjadi secara dinamis dan toleran. Keberadaan masing-masing suku dianggap setara sehingga dapat saling menghargai satu sama lain. Interaksi sosial dan amalgamasi merupakan faktor yang cukup efektif untuk menyesuaikan perbedaan-perbedaan adat dan budaya yang ada. Pementasan tarian tradisional Lampung yang diikuti pementasan tarian daerah suku pendatang moment peringatan hari besar kenegaraan dan acara resmi tertentu merupakan wujud assimilasi untuk mempersempit perbedaan dan sentimen kesukuan.

Sejalan dengan pendapat tersebut, tokoh masyarakat Lampung pada wawancara tanggal 28 Juli 2016 memaparkan bahwa:

Kehidupan suku Lampung di Kotagajah sudah banyak mengalami penyesuaian dengan kehidupan pendatang dan sebaliknya. Misalnya dalam hal pernikahan beda suku yang mengedepankan jalur pinangan dari pada larian atau ramot, begitupun sebaliknya. (Badaruddin.HW.TML/4/NS.7. tanggal 28 Juli 2016) 
Tubagus Ali Rachman Puja Kesuma|

Asimilasi dan akulturasi sudah terjadi diberbagai sektor kehidupan sosial di kecamatan Kotagajah. Proses pernikahan beda suku merupakan salah satu contoh bentuk asimilasi. Setiap adat yang memiliki tujuan sama namun berbeda tata pelaksanaannya. Hal ini dapat ditengahi dengan musyawarah agar perbedaan tersebut tidak menjadi pengahalang mencapai tujuan. Suku Lampung yang mengenal adat ngelakei/ larian (membawa pergi gadis dengan dasar suka sama suka) dan ramot (memaksa seorang gadis untuk mau menikah dengan diculik) dalam menikah, dan tentu akan tabu bagi masyarakat selain suku Lampung. Oleh karena itu, pinangan/ lamaran merupakan solusi terbaik untuk menyelesaikannya. Hal yang lain terlihat dari penggunaan prosesi dan pakaian adat yang sudah mulai menggabungkan/ mengkombinasikan kebudayaan antar suku.

Hal yang lain dapat terlihat dari lunturnya hiburan-hiburan tradisional kedaerahan pada suatu event tertentu dan digantikan dengan hiburan orgen tunggal/ dangdut yang dianggap lebih umum di semua kalangan masyarakat. Pada beberapa kasus asimilasi dan akulturasi budaya, agama sering menjadi penetralisir. persamaan agama kerap dijadikan jalan tengah misalnya hiburan qosidah dan pengajian pada resepsi tertentu.

Peran sekolah dari tingkat dasar hingga menengah juga memberikan kontribusi positif bagi regenerasi nilai-nilai integrasi sosial masyarakat kotagajah. Melalui sekolah ini siswa akan saling mengenal budaya dan kearifan lokal pribumi dan pendatang. Hal ini dilaksanakan melalui mata pelajaran bahasa Lampung, kegiatan ekstrakurikuler seni, muatan lokal dan interaksi antar warga sekolah itu sendiri. 
JIPSINDO No. 2, Volume 4, September 2017

\section{Simpulan}

Berdasarkan pembahasan hasil penelitian yang telah dilaksanakan, maka dapat disimpulkan bahwa proses interaksi di kecamatan Kotagajah berjalan dengan baik. Masyarakat memiliki kedekatan emosional yang disebabkan rasa saling ketergantungan sosial, serta ikatan kekeluargaan sebagai akibat amalgamasi dan angkon muakhi. Persaingan sosial berlangsung secara sehat, jika terjadi konflik maka hal tersebut masih dalam skala yang wajar dan merupakan paradoks dari terciptanya integrasi sosial. Penyelesaiannya pun lebih pada jalur musyawarah kekeluargaan dan hukum.

Pola interaksi yang terjadi di kecamatan Kotagajah antara lain di bidang idiologi, dimana setiap masyarakat adat/ suku memiliki idiologi/ falsafah hidup yang bernilai karakter relatif sama, dan dapat berdampingan dalam menjalankannya. Pada bidang politik, kedewasaan berdemokrasi sudah muncul di kecamatan Kotagajah. Hal ini dibuktikan dengan lunturnya politik suku dan keagamaan pada pemilihan pemimpin tertentu. Di bidang ekonomi, keterampilan hidup masing-masing suku yang diwariskan secara turun-temurun membuat kehidupan ekonomi masyarakat merata dan dapat saling mengisi satu sama lain. Adanya pasar masyarakat mampu memutus rantai ekonomi yang panjang antara produsen dan konsumen sehingga masyarakat dapat memenuhi kebutuhan hidupnya dengan harga murah. Pada bidang sosial budaya, asimilasi dan akulturasi kebudayaan terjadi untuk dapat saling menyesuaikan kehidupan sosial. Agama dan budaya modern sering kali menjadi alternatif cara untuk menengahinya. Sekolah juga memiliki peran yang efektif dalam proses integrasi sosial melalui mata pelajaran bahasa Lampung, kegiatan ekstrakurikuler dan interaksi antar warga sekolah. 
Tubagus Ali Rachman Puja Kesuma|

\section{DAFTAR PUSTAKA}

Abdulsyani. 2007. Sosiologi Skematika Teori dan Penerapan. Jakarta: Bumi Aksara.

BPS Kabupaten Lampung Tengah. 2015. Lampung Tengah Dalam Angka Tahun 2015. Lampung: BPS Kabupaten Lampung Tengah.

Gerungan, A.W. 1988. Psikologi Sosial. Jakarta: Eresco.

http://regional.kompas.com/read/2015/02/09/1721466 diakses 18 April 2016 pukul 10.05 WIB

https://www.google.co.id/maps/place/Kota+Gajah diakses tanggal 19 April 2016 pukul 10.10 WIB

Kesuma, Dharma, dkk. 2011. Pendidikan Karakter: Kajian Teori dan Praktik di Sekolah. Bandung: Remaja Rosdakarya.

Maryati, Kun dan Juju Suryawati. 2006. Sosiologi. Jakarta: Eksis.

Miles, Matthew BA and Michael Huberman. 1992. Analisis Data Kualitatif. Penerjemah Tjetjep Rohendi. Jakarta: UI Press

Monografi kecamatan Kotagajah tahun 2010

Nasikun. 2006. Sistem Sosial Indonesia. Jakarta: PT Raja Grafindo Persada

Robbins, Stephen P. 1996. Perilaku Organisasi, Konsep, Kontroversi dan Aplikasi, Alih Bahasa : Hadyana Pujaatmaka, Edisi Keenam. Jakarta: PT. Bhuana Ilmu Populer

Sa, Sabaruddin. 2013. Sai Bumi Ruwa Jurai Lampung Pepadun dan Saibatin. Jakarta: Buletin Way Lima Manjau

Siagian, Sondang P. 2004. Teori Motivasi dan Aplikasinya. Jakarta: PT. Rineka Cipta

Wirawan. 2013. Konflik Dan Manajemen Konflik (Teori, Aplikasi, dan Penelitian). Jakarta: Salemba Humanika, 2013)

Wulansari, Dewi. 2009. Sosiologi Konsep dan Teori. Jakarta: PT Refika Aditama

\section{Wawancara:}

Rudiyanto, Tokoh Masyarakat Suku Jawa di kecamatan Kotagajah. Tanggal 28 Juli 2016

Dwi Haryono, Aparatur Pemerintahan Kabupaten Lampung Tengah. Tanggal 30 Juni 2016

Badaruddin, Tokoh Masyarakat Suku Lampung. Tanggal 28 Juli 2016 